\title{
Thought And 2nd Language: A Vygotskian Framework For Understanding Bics And Calp
}

\author{
James Bylund, Psy.D., ABSNP
}

\begin{abstract}
Dr. James Bylund é doutor em Psicologia educacional pela Alliant International University, em San Diego, na Califórnia. Mestre em Educação e Especialista em Psicologia Educacional pela San Diego State University, na Califórnia, EUA. É Especialista em neuropsicológica educacional e Credenciado a atuar como Psicólogo Educacional em todo território dos Estados Unidos. Trabalhou como psicólogo nas escolas públicas de San Diego e como coordenador de programas especiais na região de Contra Costa, na Califórnia, EUA. Atualmente, é diretor de serviços de apoio ao estudante nas escolas públicas de Byron, na Califórnia, atende em seu consultório particular e leciona cursos de avaliação neuropsicológica na Alliant International University.
\end{abstract}

\begin{abstract}
Language diversity has been a defining characteristic of U.S. public schools throughout their history, and this phenomenon shows no signs of slowing down. Over the 10 year period between 1994-1995 and 2004-2005, the number of students in US public schools classified as Limited English Proficient (LEP) grew from roughly 3.2 to 5.1 million, an increase of 57\% (National Clearinghouse for English Language Acquisition). Public schools are responsible for educating students from diverse linguistic backgrounds, and efforts to do so have often involved immersing these students in English-only programs at the expense of their primary language.
\end{abstract}

Keywords: Language Acquisition, language development, public schools throughout, Vygotsky.

\section{Introduction}

Rhodes, Ochoa, and Ortiz (2005) point out the common misconception held by many in the general public, including the parents of second language learners and school personnel, that bilingual education may adversely affect a student's English language development. The authors refer to this phenomenon as the "immersion myth" (Rhodes, Ochoa, \& Ortiz, 2005, p. 58). Unfortunately, the immersion myth has lead to placement decisions that do not produce desired educational outcomes. As a group, LEP students are performing far below their monolingual English speaking peers across numerous indicators including standardized test performance, retention rates, and the number of students dropping out of school (Rhodes, Ochoa, \& Ortiz, 2005). 
Across the country, second language learners are participating in English-only programs, pull-out English as a second language (ESL) instruction, content-based ESL, transitional bilingual programs, maintenance bilingual programs, and dual language bilingual programs (Ochoa \& Rhodes, 2005). However, while a wide range of different programs are currently in place, the long term outcomes for students in these programs vastly differ. Rhodes, Ochoa, and Ortiz (2005) cite research conducted by Thomas and Collier in illustrating the fact that LEP students initially make similar gains in English language reading development regardless of the type of language instruction they receive (e.g. ESL Pullout or Two-Way Bilingual Education). However, this pattern is short lived. The short term gains experienced by students in transitional and ESL programs begins to level off, or even disappear over time, while students in maintenance bilingual education programs continue to progress in their English language reading skills well into their high school careers, eliminating the achievement gap between themselves and their monolingual English speaking peers. In fact, primary language instruction for four or more years has a positive impact on academic achievement that may mitigate the risk of low socioeconomic status faced by many language minority students (Thomas \& Collier, 2002).

\section{Bics Vs Calp}

Clearly, these studies demonstrate the positive long term impact of primary language instruction on the development of students' English language academic skills. But how could this be? How could instruction in, let's say Spanish, benefit a student's English literacy development. In order to answer this question, researchers often point to the work of Cummins (1981) who proposed that two distinct types of language proficiency exist, Basic Interpersonal Communications Skills (BICS) and Cognitive/Academic Language Proficiency (CALP). BICS includes aspects of language such as basic vocabulary and pronunciation, skills that are readily apparent during conversations between two or more people. Often times this type of interpersonal communication is heavily dependent on the context in which the conversation is taking place since the meanings of words are often dependent upon "situational and paralinguistic clues" (Cummins, 1981, p. 23). On the other hand, CALP refers to language skills that allow an individual to process and make meaning of language that exists independent of any situational clues, and is the language skill required for meaningful engagement in most academic tasks. LEP Students' command of BICS is often times very misleading in that they may possess surface level language skills, and be able to carry on a 
conversation in English, yet lack the CALP skills necessary for success in academic settings.

Cummins (1981) proposed that the best way for a student to develop CALP in their second language was to first develop CALP in their primary language. In fact, a student may not be able to develop CALP in their second language until they have first reach some minimum threshold in their primary language (Rhodes, Ochoa, \& Ortiz, 2005). This phenomenon is due to what Cummins (1981) referred to as a Common Underlying Proficiency (CUP). According to Cummins (1981), an individual's mastery of their primary language (L1) supports the development of a second language (L2) because of common underlying features across languages such as the ability to generate meaning from disembedded words and phrases. Consistent with Cummin's theory, Thomas and Collier (2002) found that "the strongest predictor of L2 achievement is amount of L1 schooling. The more L1 grade level schooling, the higher L2 achievement" (cited in Rhodes, Ochoa, \& Ortiz, 2005, p. 72).

\section{Vygotsky's Thought And Language}

While Cummins has made invaluable contributions to our understanding of second language development and the need for bilingual education, his theory of BICS and CALP is largely descriptive and does not explain the underlying cognitive processes involved in second language development. A previous theorist, however, writing more than 45 year years before Cummins, provides us with additional insight into this process. Lev Vygotsky, the acclaimed Russian Psychologist, describes in his classic book Thought and Language the use of language as a psychological tool for the purpose of analyzing and solving complex problems. The ability to do so, a stage in language development that Vygotsky (1986/1934) refers to as the use of "concepts", is essentially the equivalent of Cummins' CALP, and is described in the following paragraphs.

Too often as educators, we focus our attention the external features of language such as pronunciation, fluency, and grammar, in other words BICS, while overlooking the role that language plays in complex thought processes. According to Vygotsky (1986/1934), language development unfolds along a continuum beginning with the unorganized assignment of symbols (words) to various objects, and culminating in a final stage of mature conceptual thinking. He used the terms "inner speech" and "verbal thought" to refer to our use of language as a psychological tool when engaging in higher level cognitive activities. This function is a uniquely human capacity that allows us to move beyond our immediate experience and form relationships between pieces of information, establish patterns, and make predictions. 
Cummins attributes the transfer of CALP in L1 to CALP in L2 to a Common Underlying Proficiency (CUP). However, in order for CALP skills to transfer between languages that differ in terms of their external characteristics, the essence of what transfers must be related to, yet separate, from the languages themselves. Vygotsky's work suggests that what transfers is the use of mature "concepts" as part of one's "verbal thought", a final stage of language development in which we use concepts as cognitive tools for creating meaning out of our experiences. This final stage is not language per se, but a coming together of thought and language. According to Vygotsky (1986/1934), "verbal thought" facilitates complex thought processes by selecting, organizing, and imprinting essential pieces of information, as well as exploring multiple meanings within subordinate and superordinate categories.

Students who lack the necessary concepts will not be able to fully comprehend certain pieces of information even though they may have knowledge of the individual words. Vygotsky $(1986 / 1934)$ proposed that a concept was not a static formation, but rather a dynamic entity that both influences the thought process, in generating ideas and solving problems, and is influenced by the process of thinking, thus changing as new relationships are discovered. In turn, a child's ability to use verbal thought as a cognitive tool develops as she accumulates a widening range of word meanings and forms a framework or structure connecting the concepts represented by those words. This semantic map allows her to then transcend her immediate experience by making associations that transform information into entirely new ideas.

While thought and language are inextricably linked, Vygotsky (1986/1934) proposed that thought and language develop along separate paths. He wrote that there is a "prelinguistic phase in the development of thought and a preintelectual stage in the development of language" (p. 80). Vygotsky (1986/1934) outlined the relationship between thought and language as two forces that initially exist and develop along separate paths but which, at a certain point in development, become intertwined with one another, as the development in one in turn promotes the development of the other. Therefore, the use of "concepts" as part of verbal thought is not a quantitative extension of one's accumulation of individual words, but rather a qualitative change in the way a person uses language to think about information. As such, CALP is more than simply a developmental extension of BICS, which may be implied by statements such as 'it takes 2-3 years to develop BICS but 5-7 years to develop CALP'. CALP is a qualitatively different use of language than BICS, which is dependent upon both language development and cognitive development. In 
other words, CALP is not simply language but rather the intersection of thought and language.

While children begin to use words rather early in their development, their understanding and use of concepts occurs much later. Vygotsky $(1986 / 1934)$ found that a major shift in the use of verbal concepts for the purpose of abstract reasoning occurred in adolescents. This shift is dependent upon two converging factors. First, Vygotsky (1986/1934) found that prior to age twelve, roughly speaking, a child's mind is not capable of using abstract concepts to transcend beyond their immediate experience. Second, over the course of language development, words take on increasingly differentiated meanings and associations, and it isn't until adolescence that children have developed a vocabulary rich enough in order to create an intricate semantic map. Interestingly, the point at which language development and cognitive development collide, corresponds with Cummin's (1981) findings that development of CALP requires $5-7$ years of formal schooling, in a language that the child comprehends, beginning in kindergarten or $1^{\text {st }}$ grade. In such cases, these students would be roughly 11 to 13 years old.

In examining the development of speech and intellect, and comparing that with the development of verbal thought, Vygotsky $(1986 / 1934)$ concluded that verbal thought is not natural outcome of early speech and intellectual development. In fact, Vygotsky (1986/1934) concluded that, while speech and intellect have a biological genesis, verbal thought is determined by socio-cultural processes with characteristics that are distinct from both thought and speech alone. Schools are our cultural institutions assigned with the explicit responsibility of developing children's thought processes. In young children the transfer of already formed concepts to new situations does not occur automatically, and as such, when a child's language is disrupted at an early age without the direct and intentional effort of adults to create a structure linking what she already knows (L1) with what she is learning (L2), a conceptual organization of word meanings may not occur. This has tragic implications for the development of the child's thought processes.

If, at an early age, a child is immersed in instruction provided in a language that they have yet to master, without intentional efforts to build transfer between L1 and L2, their development of "concepts" is likely to be markedly impaired when compared to their monolingual peers. Obviously the genesis of such impairment does not reside within the child but rather in the social transmission of knowledge. By placing a LEP students into classes that are taught only in English at least two things happen. First, they are disconnected from all of the verbal knowledge that they bring with them to school thus stifling 
the development of their primary language skills. Second, while they begin to accumulate knowledge of their second language, they are doing so years behind their monolingual English speaking peers and are therefore unable to access the curriculum in the same manner. Both of these factors, resulting in immature "concepts" in both L1 and L2, in turn impair a student's development and use of verbal thought.

When developed fully, a student's primary language can provide an established and organized system of meaning that can be applied to new learning situations, including those in which information is presented in a second language that the student is learning. In other words, an individual can use concepts that are already well developed in their primary language in order facilitate learning and problem solving in their second language. In turn, learning a second language then serves to simultaneously promote further learning and concept formation in their primary language. As Vygotsky (1986/1934) wrote:

[S]uccess in learning a foreign language is contingent on a certain degree of maturity in the native language. The child can transfer to the new language the system of meanings be already possesses in his own. The reverse is also true - a foreign language facilitates mastering the higher forms of the native language. The child learns to see his language as one particular system among many, to view its phenomena under more general categories, and this leads to awareness of bis linguistic operations” (pp. 195-196).

On the other hand, if a student has not first developed concepts in their primary language they do not have the necessary structures in place for the types of learning and problems solving required in school.

\section{Conclusion}

When working with students who are learning English as a second language, we too often focus our attention on the external features of language such as pronunciation, fluency, and grammar while overlooking the role of language as a cognitive tool used in complex thought processes. In Thought and Language, Vygotsky (1986/1934) explores the use of verbal thought, and describes it not merely as speech turned inward, but rather the use of word meanings, or better yet concepts, as cognitive tools that facilitate higher level thinking. The use of language as a cognitive tool allows us to move beyond our immediate perceptual experience in order to engage in abstract thinking and novel problem solving. We use verbal thought to direct our attention, set goals, determine strategies, explore multiple meanings, make inferences, and draw conclusions. 
In contrast to words, concepts make up an organized structure of relationships and generalities. The ability to think in terms of concepts, therefore, allows us to transcend our immediate experience in order to explore past, future, and hypothetical situations. As I attempted to describe in this essay, the differences between words and concepts, and the use of concepts in complex thought processes, has important implications in terms of how we understand second language development and how we choose to educate children whose primary language is not English. If, at an early age, a child is immersed in instruction provided in a language they have yet to master, without intentional effort to build transfer between L1 and L2, their development of organized conceptual structures is disrupted and likely to be markedly impaired as a result. Clearly, the genesis of such impairment does not reside within the child but rather is social in nature in that it results from the interaction between the child and the educational system.

While numerous types of programs are available to second language learners throughout the country, only maintenance bilingual and dual immersion bilingual programs have been demonstrated to be successful in closing the achievement gap between LEP students and their monolingual peers. Other programs such as ESL and transitional bilingual classes may produce initial gains in English language skills, but these early gains do not lead to sustainable long term improvements in academic performance. Such programs promote the development of BICS, the surface level language skills, while failing to develop the CALP skills, in other words the semantic map, necessary for success in academic settings.

\section{References}

CUMMINS, J. (1981). Empirical and theoretical underpinnings of bilingual education. Journal of Education. 163, 16-30.

National Clearinghouse for English Language Acquisition. (2006). The Growing Numbers of LEP Students. Retrieved June 8, 2010, from http://www.ncela.gwu.edu/files/uploads/4/Gro wing LEP 0506.pdf.

OCHOA, S.H., \& Rhodes, R.L. (2005). Assisting parents of bilingual students to achieve equity in public school. Journal of Educational \& Psychological Consultation. 16, 75-94.

RHODES, R.L, Ochoa, S.H., \& Ortiz, S.O. (2005). Assessing culturally and linguistically diverse students: A practical guide. New York. Guilford Press.

THOMAS, W.P. \& Collier, V. P. (2002). A national study of school effectiveness for language minority students' long term academic achievement. Executive Summary. Santa Cruz, CA: Center for Research on Education, Diversity, and Excellence. Retrieved June $\quad$ 8, 2010, from 
http://www.usc.edu/dept/education/ CMMR/CollierThomasExReport.pdf.
Vygotsky, L.S. (1986). Thought and Language. Cambridge, MA: MIT Press (Original work published 1934) 